\title{
Soil Contamination with Heavy Metals and Its Impact on Food Security in China
}

\section{Zhongchen $\mathrm{Hu}^{1}$, Jianwu $\mathrm{Li}^{{ }^{*}}$, Hailong Wang1,2*, Zhengqian Ye1, Xudong Wang ${ }^{1}$, Yongfu Li ${ }^{1}$, Dan Liu ${ }^{1}$, Zhaoliang Song ${ }^{3}$}

\author{
${ }^{1}$ Zhejiang Provincial Key Laboratory of Carbon Cycling in Forest Ecosystems and Carbon Sequestration, Zhejiang A\&F \\ University, Hangzhou, China \\ ${ }^{2}$ School of Environmental and Chemical Engineering, Foshan University, Foshan, China \\ ${ }^{3}$ Institute of the Surface-Earth System Science Research, Tianjin University, Tianjin, China \\ Email: `jameslee@zafu.edu.cn, ^nzhailong@yahoo.com
}

How to cite this paper: $\mathrm{Hu}, \mathrm{Z}$. C., Li, J. W., Wang, H. L., Ye, Z. Q., Wang, X. D., Li, Y. F., Liu, D., \& Song, Z. L. (2019). Soil Contamination with Heavy Metals and Its Impact on Food Security in China. Journal of Geoscience and Environment Protection, 7, 168-183.

https://doi.org/10.4236/gep.2019.75015

Received: March 5, 2019

Accepted: May 27, 2019

Published: May 30, 2019

Copyright $\odot 2019$ by author(s) and Scientific Research Publishing Inc. This work is licensed under the Creative Commons Attribution International License (CC BY 4.0).

http://creativecommons.org/licenses/by/4.0/

\begin{abstract}
With the rapid economic expansion, environmental degradation has become increasingly sever during the past three decades. Soil pollutions associated with toxic organic compounds and heavy metals have been identified in China. The accumulation of heavy metals in soils and its impact on food safety is of increasing concern. It has been reported that more than 20 million ha of land have been contaminated with heavy metals that can result in the potential health risks to human beings and soil ecosystems. This can potentially jeopardize the food security in China. Accumulation of heavy metals in suburb and rural soils is closely related to many anthropogenic activities, such as application of fertilizers and pesticides, irrigation of wastewater, discharge of mining, improper disposal of metal containing wastes, land application of animal manures, sewage sludge and coal combustion residues. Arable crops and vegetables in suburb and rural can take up heavy metals from contaminated soils, which is one of the main pathways of introducing heavy metals to human food chain. Events related to soil and vegetable contamination, food safety and human health risks, e.g., rice and vegetables with elevated concentrations of cadmium, are often reported in the media in recent years. The Chinese government has recently developed a number of new policies for prevention of soils from further soil contamination, and remediation of contaminated soils. This presentation will provide a comprehensive review on heavy metal pollution in soils and its impacts on food security in China, and also summarize some new technologies for remediation of soils contaminated with heavy metals.
\end{abstract}

\section{Keywords}

Soil, Heavy Metals, Food Security, China 


\section{Introduction}

Since food is the paramount necessity of the people, food security is the prerequisite for human survival and the fundamental guarantee for human healthy. A variety of food contamination issues have led to food scares and public attention to food safety in recent years (Sriprachote et al., 2012; Akhtar, 2013; He et al., 2013). In China, food security issues, such as percent of pass food and poisoning food-borne disease, happen occasionally in China (Zhang et al., 2005; Li et al., 2013). So food security and safety are becoming hot topics and have been written into document at the Fifth Plenary Session of the 15th Congress of CPC in China.

The potential impact of heavy metals, pesticide residues and numerous adulterants on food security is one of the most important public health issues worldwide (Miraglia et al., 2009; Wei \& Yang, 2010; Akhtar, 2013; Sun et al., 2013). Because of their toxicity, non-biodegradability and persistence, heavy metals are especially dangerous (Yan et al., 2013). Heavy metals constitute an ill-defined group of inorganic chemical hazards, and those most commonly found at contaminated sites are lead $(\mathrm{Pb})$, chromium $(\mathrm{Cr})$, arsenic (As), zinc $(\mathrm{Zn})$, cadmium $(\mathrm{Cd})$, copper $(\mathrm{Cu})$, mercury $(\mathrm{Hg})$, and nickel $(\mathrm{Ni})$ (Lu et al., 2011). Heavy metal pollution not only affects the production and quality of crops, but also can cause problems in the aerosphere and water bodies, and may be finally accumulated in the human body, causing serious health problems (Kapaj et al., 2006; Zheng et al., 2007; Lai et al., 2010; Wei \& Yang, 2010; John \& Andrew, 2011; Lin et al., 2013; Fu \& Wei, 2013). Unlike organic contaminants that are oxidized to carbon oxide by microbial action, most heavy metals do not undergo microbial or chemical degradation (Kirpichtchikova et al., 2006), thus heavy metals in soils persist for a long time (Adriano, 2003) and their presence can severely inhibit the biodegradation of organic contaminants (Maslin \& Maier, 2000). As the primary reservoir of heavy metals in the atmosphere, hydrosphere and biota, soil serves vital function for food production and safety (Micó et al., 2006; Cao et al., 2010; Akhtar, 2013). Therefore, soil heavy metal pollution has also become of great concern to the public (Liu et al., 2006; Rogan et al., 2009; Römkens et al., 2009; He et al., 2013).

China has made outstanding economic progress since 1990, however, food security level of China is still inferior (Chen, 2007; Fu \& Wei, 2013; Li et al., 2013). Remarkably, with the rapid economic growth and consequential food security accidents in recent years, soil heavy metal pollution and its negative influence on food security and human health has also aroused people's wide concern in China (Zhang et al., 2005; Howard \& Sammy, 2012; Li et al., 2013; Wu \& Chen, 2013). Therefore, the aim of the present review is to: 1) clarify the pollution of soil heavy metals in an agricultural urban soils; 2) find out the possible sources of heavy metals contamination in soils; 3 ) provide a comprehension of the impact of soils heavy metal pollution on food and human body and 4) propose measures to control and limit the accumulation of heavy metals in soils and 
food crops.

Heavy metals in soil pose potential threats to the environment and can damage human health (Park et al., 2004; Al-Saleh et al., 2004; Komárek et al., 2008; Lu et al., 2011) through following approaches: 1) direct ingestion or contact with contaminated soil, 2) the food chain, 3) drinking of contaminated ground water, 4) reduction in food quality via phytotoxicity and 5) reduction in land usability for agricultural production causing food insecurity (McLaughlin et al., 2000; Ling et al., 2007).

\section{Heavy Metal Pollution of Soils}

Soil serves many vital functions in our society, particularly for food production. It is thus of extreme importance to protect this resource and ensure its sustainability. With the rapid development of industry and the economy, more and more pollutants are being released into soils (Kachenko \& Singh 2006; Montagne et al., 2007; Li et al., 2008; Yang et al., 2009). Excessive accumulation of heavy metals (e.g., $\mathrm{Pb}, \mathrm{Cr}, \mathrm{As}, \mathrm{Zn}, \mathrm{Cd}, \mathrm{Cu}, \mathrm{Hg}$ and $\mathrm{Ni}$ ) in soils may not only result in soil contamination, but also lead to elevated heavy metal uptake by crops, and thus affect food quality and safety (Park et al., 2004; Al-Saleh et al., 2004; Komárek et al., 2008; Lu et al., 2011). Thus, heavy metal pollution in soils has become an important issue both in developed and developing countries (Nicholson et al., 2003).

\subsection{Heavy Metals in Agricultural Soils}

Because heavy metals have the characteristics of toxicity, non-biodegradability and persistence, they are especially dangerous relative to different kinds of contaminants (Yan et al., 2013). Because of the potential human health risks, heavy metal accumulation in soils-plants system has led to a growing public concern (Wei \& Yang, 2010; Fu \& Wei, 2013). Meanwhile, the heavy metal contamination of soils has also received increased attention in China in recent years (Chen, 2007; Huang et al., 2007; Wei \& Yang, 2010; Li et al., 2013).

Heavy metal contamination of soils has been reported in several provinces of China in recent several decades (Table 1; Huang et al., 2007; Liu et al., 2005; Wang et al. 2003; Zhao et al., 2007). Although the geological background levels of heavy metals are low in China, the mean concentrations of $\mathrm{Cu}(40.42), \mathrm{Pb}$ (39.32), Zn (119.95), Ni (32.05), Cd (0.50) and $\mathrm{Hg}(0.31) \mathrm{mg} / \mathrm{kg}$ (dry mass) in agricultural soils of all the 15 cities are higher than their background values (Table 1). This indicates that the agricultural soils are under contaminated by the heavy metals. Wei and Yang (2010) also calculated the Igeo values for Cd and $\mathrm{Hg}$ in agricultural soils of China are higher than 1 . Results suggest that the agricultural soils are significantly contaminated by $\mathrm{Cd}$ and $\mathrm{Hg}$ in many cities of China. Especially, the Igeo values for $\mathrm{Cd}$ and $\mathrm{Hg}$ are highest in the agricultural soils of Xuzhou and Guangzhou, respectively, indicating the agricultural soils may be considerably contaminated by $\mathrm{Cd}$ and $\mathrm{Hg}$ in the two cities. There 
Table 1. Concentrations of heavy metals in agricultural soils of China (mg/kg).

\begin{tabular}{|c|c|c|c|c|c|c|c|c|}
\hline Site & $\mathrm{Cu}$ & $\mathrm{Zn}$ & $\mathrm{Ni}$ & $\mathrm{Pb}$ & $\mathrm{Cr}$ & $\mathrm{Hg}$ & As & $\mathrm{Cd}$ \\
\hline Beijing & 28.1 & 81.1 & & 18.5 & 75.7 & & & 0.18 \\
\hline Shanghai & 31.4 & 106.2 & & 26.4 & 85.6 & 0.13 & 7.8 & 0.20 \\
\hline Nanjing & 33.2 & 87.8 & & 45.6 & & & & 0.66 \\
\hline Guangzhou & 24.0 & 162.6 & & 58.0 & 64.7 & 0.73 & 10.9 & 0.28 \\
\hline Wuhan & 36.0 & 113.0 & 26.0 & 19.0 & & 0.43 & & 0.69 \\
\hline Changsha & 35.1 & 153.4 & 31.1 & 55.1 & 32.9 & & 17.3 & 0.54 \\
\hline Xiangtan & 41.5 & 158.0 & 31.0 & 66.6 & 29.4 & & 17.3 & 0.75 \\
\hline Zhuzhou & 35.6 & 183.3 & 30.6 & 104.3 & 31.5 & & 18.0 & 1.04 \\
\hline Hengyang & 31.0 & 110.1 & 29.7 & 44.4 & 26.7 & & 16.1 & 0.39 \\
\hline Cixi & 34.0 & 88.9 & & 28.1 & & & & 0.15 \\
\hline Dongguan & & & & 69.2 & 40.6 & 0.26 & 15.2 & 0.92 \\
\hline Nanchang & 43.1 & 101.4 & 25.1 & 45.7 & 57.6 & 0.64 & 18.1 & 0.21 \\
\hline Lanzhou & 41.6 & 69.6 & & 37.4 & & & 17.3 & \\
\hline Zhengzhou & & & & 17.1 & 67.7 & 0.08 & 6.7 & 0.12 \\
\hline Yangzhou & 33.9 & 98.1 & 38.5 & 35.7 & 77.2 & 0.20 & 10.5 & 0.30 \\
\hline Wuxi & 40.4 & 112.9 & & 46.7 & 58.6 & 0.16 & 14.3 & 0.14 \\
\hline Taihang & 21.2 & 70.0 & 25.0 & 18.8 & 57.8 & 0.08 & 6.2 & 0.15 \\
\hline Chengdu & 42.5 & 227.0 & & 77.3 & 59.5 & 0.31 & 11.3 & 0.36 \\
\hline Hainan & 30.3 & 52.2 & 15.5 & 48.0 & 22.7 & & 8.1 & 0.28 \\
\hline Jinghe & & & & 22.4 & 44.2 & & 14.9 & 0.14 \\
\hline Kunshan & 34.3 & 105.9 & 31.1 & 30.5 & 87.7 & 0.20 & 8.2 & 0.20 \\
\hline Xuzhou & 35.3 & 149.7 & & 56.2 & & & & 2.57 \\
\hline Tianjin & 73.0 & & 44.0 & 36.0 & & 0.80 & 10.7 & 0.61 \\
\hline Baiyin & 99.3 & 147.0 & 44.2 & 84.1 & & & & 0.98 \\
\hline China Background & 22.6 & 74.2 & 26.9 & 26.0 & 61.0 & 0.07 & 11.2 & 0.10 \\
\hline
\end{tabular}

Note: China Background $=$ background values in soil of China.

are over 12,000 ha Cd polluted soils in 11 irrigation regions of China (Liao, 1993). Large amounts of soil Cd have accumulated in China soils that the Cd content in heavily polluted soil reaches levels of $5-7 \mathrm{mg} / \mathrm{kg}$ and the content in rice is $1-2 \mathrm{mg} / \mathrm{kg}$ in the Zhangshi irrigation area. The average concentrations of soil $\mathrm{Cd}, \mathrm{Cu}$ and $\mathrm{Zn}$ in Wenling (Zhejiang province of China) were higher than their local background values, and the mean values of soil $\mathrm{Cu}$ and $\mathrm{Cd}$ increased during the past 5 years soil (Li et al., 2014). Since long farmed history, the contents of $\mathrm{Cu}$ and $\mathrm{Pb}$ also have been high and a common pollution in vegetable fields of China (Zhang \& Gong 1996). Therefore, the soil pollution of heavy metals is widespread in agricultural soils in China.

Owing to rapid economic development, heavy metal contamination of agri- 
cultural soils has become increasingly serious in China (Li et al., 1997; Liu et al., 2005; Huang et al., 2007; Li et al., 2016). The main pollution sources of heavy metals are different in different areas (Huang et al., 2007; Liu et al., 2005; Wang et al., 2003; Zhao et al., 2007). The sources of $\mathrm{Cu}, \mathrm{Pb}, \mathrm{Zn}$ and $\mathrm{Ni}$ in the agricultural soils of Xuzhou and Guangzhou may be mainly derived from industrial sources. The sources of the metals in agricultural soils are mainly influenced by sewage irrigation in Beijing and Zhengzhou. However, the sources of the metals in agricultural soils in the other cities may be mainly influenced by parent materials, urban effluent and vehicle exhausts. On the other hand, the increasing reliance on agrochemicals for higher yields is also an important source of heavy metals in agricultural soils (Li et al. 1997). Today's agriculture in China has become increasingly reliant upon agrochemical usage (Li et al., 1997a \& 1997b). According to the Food and Agriculture Organization, the use of inorganic fertilizer in China increased by about 100 times from $3.9 \mathrm{~kg} / \mathrm{ha}$ in 1949 to $379 \mathrm{~kg} / \mathrm{ha}$ in 1995, which was more than 2.5 times of the world's average. Moreover, China is the world's second largest producer of pesticide, and there was more than $260,000 \mathrm{t}$ of pesticide production in 1994. About $90 \%$ of the pesticides is used on crops (Li et al., 1997a). Some fertilizers and pesticides are known to contain various levels of heavy metals, including $\mathrm{Cd}$ and $\mathrm{Cu}$. Thus, agricultural soils and crops are suffering from increasing damage from heavy metals in China.

\subsection{Heavy Metal Pollution in Urban Soils}

As the urban population continues to grow, more and more attention has been given to the influence of heavy metal pollution of urban soils on urban eco-environment and human health. Many studies have indicated that urban soils are contaminated by heavy metals in China (Figure 1; Lu et al., 2003; Li et al., 2013). Heavy metals in urban soils can be accumulated in human body via directly inhalation, ingestion and dermal contact absorption (Madrid et al., 2002; Ferreira-Baptista \& De Miguel 2005; De Miguel et al., 2007; Poggio et al., 2008; Marjorie et al., 2008; Lim et al., 2008). In addition, intake of heavy metals via the soil-crop system has been considered as the predominant pathway of human exposure to environmental heavy metals in suburb area (Liu et al., 2007). In China, due to the modern industries, traffic and mining activities and rapid urbanization in urban areas, the heavy metal contamination of urban soils has become increasingly serious during the last two decades (Wei \& Yang, 2010).

In China, heavy metal pollution in urban soils becomes serious with the rapidly industrialization and urbanization, thus quite a few studies associated with heavy metal contamination in urban soils have been carried out in recent decades (Figure 2; Wei \& Yang, 2010). Although the geological backgroundlevels of heavy metals are low in China, soil, water, air and plants are polluted by heavy metals in many cities. Heavy metal pollution of soils do harm to human health through the directly intake or the food chain (Lu et al., 2011). Heavy metal pollution in urban soil is present in various cities, such as Beijing 


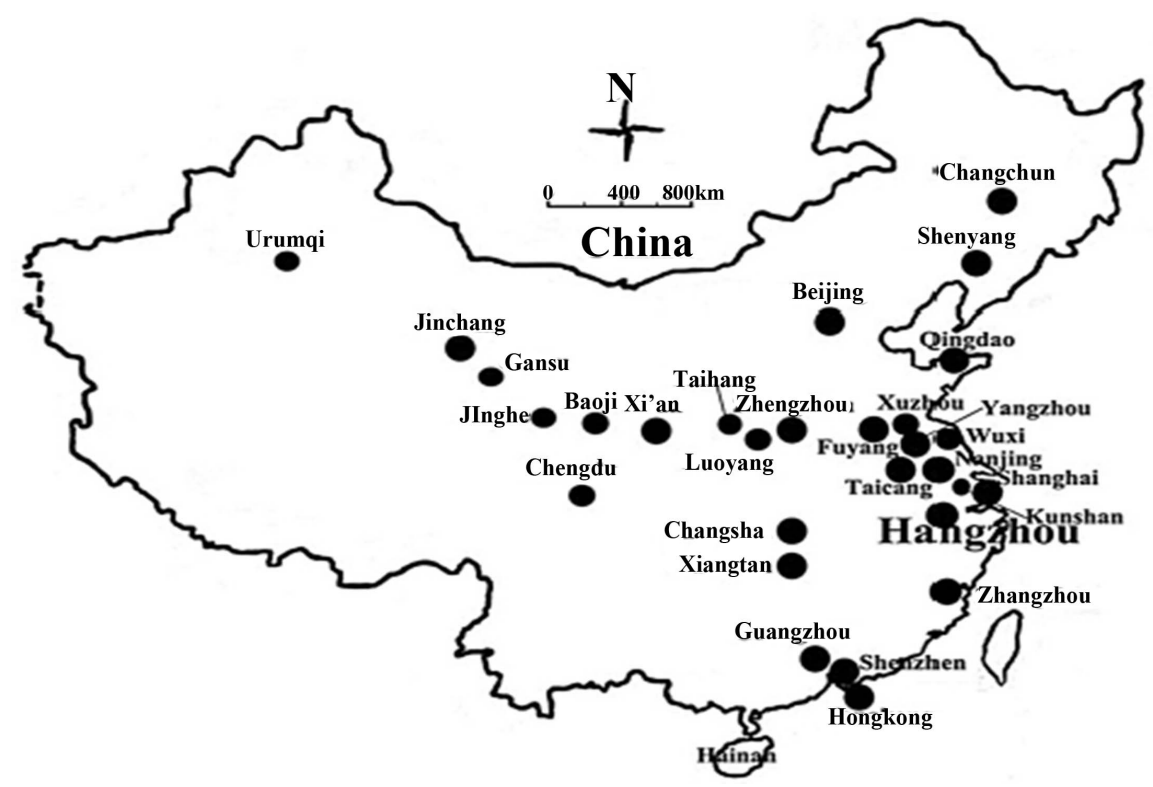

Figure 1. Distribution of urban soils with heavy metal contaminations in China.
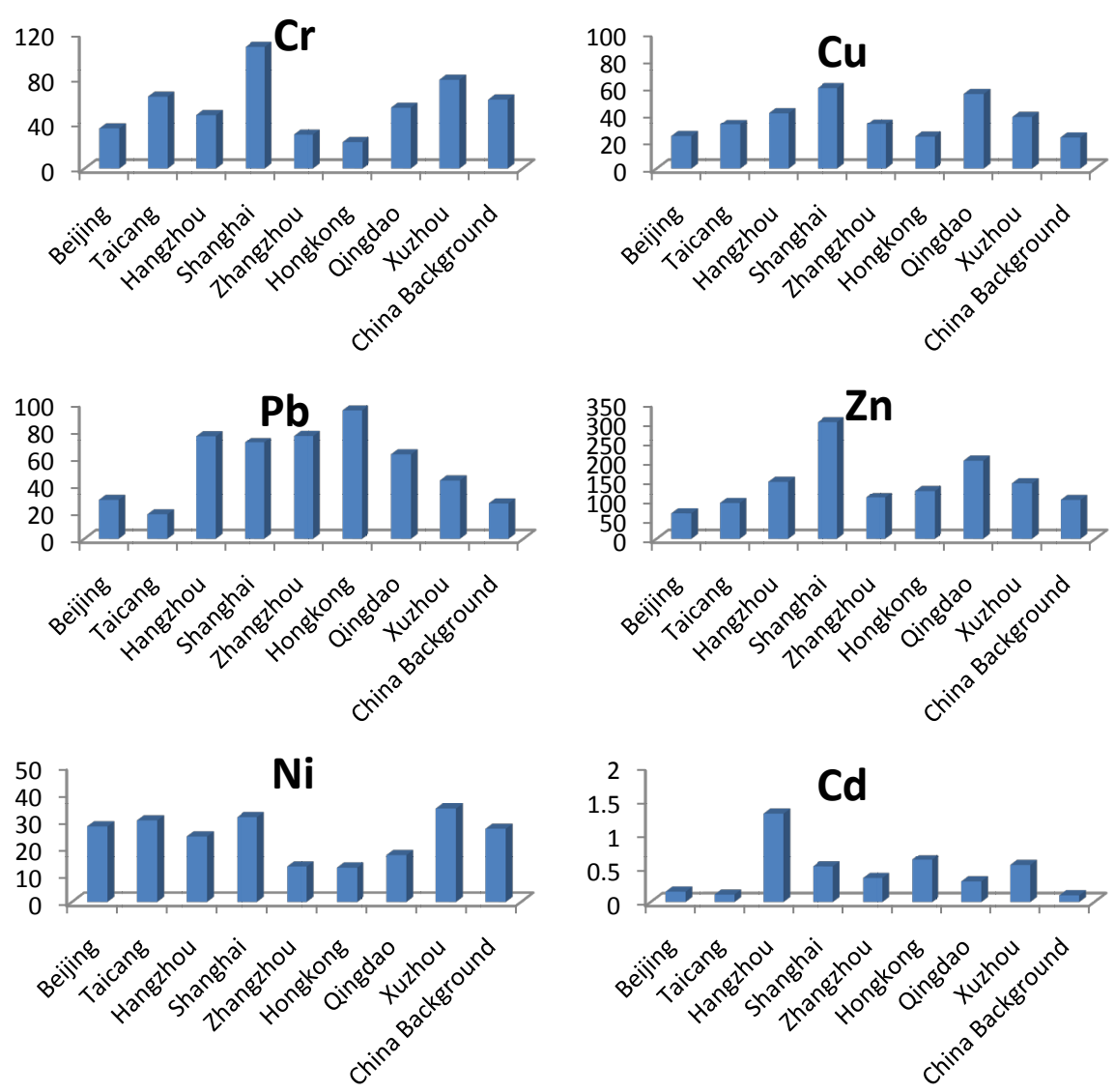

Figure 2. Concentrations of heavy metals in urban soils from the cities in China (mg/kg).

and Shanghai. Significant enrichment of lead $(\mathrm{Pb})$, zinc $(\mathrm{Zn})$, copper $(\mathrm{Cu})$, chromium (Cr) and cadmium (Cd) in urban soil of Shanghai has been reported. 
Most of the concentrations of heavy metals in urban soils are higher than their background values (Figure 2). The $\mathrm{Pb}$ concentrations of urban soils in Beijing, Qingdao, Hangzhou, Shanghai, Zhangzhou, Hongkong and Xuzhou are much higher than their background values. It is significantly apparent that the $\mathrm{Cd}$ and $\mathrm{Cu}$ concentrations of urban soils in the cities are all exceed their background values. The highest concentrations of $\mathrm{Cr}, \mathrm{Cu}, \mathrm{Pb}, \mathrm{Zn}$ and $\mathrm{Cd}$ are also found in the cities of Shanghai, Shanghai, Hongkong, Shanghai and Hangzhou, respectively. Moreover, several studies of soil metal contamination in Chinese cities also concluded that heavy metal contamination is widespread in urban soils (Wei \& Yang, 2010).

The cause of heavy metal accumulation in soils can be either natural or anthropogenic (Krzysztof et al., 2004), including industries (Jan et al., 2010; Chabukdhara \& Nema, 2013) and urbanization (Chen, 2007). Generally speaking, the sources of $\mathrm{Cd}, \mathrm{Cu}, \mathrm{Pb}, \mathrm{Zn}, \mathrm{Cr}$ and $\mathrm{Ni}$ in urban soils are mainly derived from traffic emission and industrial emission. The main pollution sources of the metals are different among the cities. The pollution sources of the heavy metals in the urban soils of Shenyang, Baoji, Guangzhou and Changchun may be mainly derived from industrial emission and traffic emission, while the heavy metals in Beijing, Shanghai, Wenzhou, Qingdao and other cities may be mainly derived from traffic emission. Therefore, human activities, such as industrial and energy production, vehicle exhaust, waste disposal, and coal and fuel combustion are all potential sources for heavy metals to urban soils.

\section{The Impact of Heavy Metals on Food Security}

With the development of industrialization and consequential food security accidents, soil heavy metal pollution has became of great concern to the public ( $\mathrm{He}$ et al., 2013; Liu et al., 2006; Rogan et al., 2009; Römkens et al., 2009). Cultivation of crops for human or livestock consumption on contaminated soil can potentially lead to the uptake and accumulation of heavy metals, and chronic intakes of heavy metals have damaging effects on human beings and other animals (Zheng et al., 2007; Lai et al., 2010; John \& Andrew, 2011). Thus, heavy metal pollution of soil has an important influence on the health of human beings (McBride, 2007; Demek-Poprawa \& Sawicka-Kapusta, 2004; Akhtar, 2013; He et al., 2013; Sriprachote et al., 2012). It has been reported that serious systemic health problems can develop as a result of excessive dietary accumulation of heavy metals such as $\mathrm{Cd}$, and $\mathrm{Pb}$ in the human body (Oliver, 1997). Although $\mathrm{Zn}$ and $\mathrm{Cu}$ are essential elements, their excessive concentration in food and feed plants are of great concern because of their toxicity to humans and animals (Kabata-Pendias \& Mukherjee, 2007). Lead and Cd are considered potential carcinogens and are associated with etiology of a number of diseases, especially cardiovascular, kidney, nervous system, blood as well as bone diseases (Jarup, 2003). Soil and vegetables polluted with $\mathrm{Pb}$ and $\mathrm{Cd}$ can lead to decrease of human life expectancy within the affected areas. Pruvot et al. (2006) and Bosso and 
Enzweiler (2008) showed that children living around a former smelter had high blood $\mathrm{Pb}$ levels in France and Brazil. Although $\mathrm{Zn}$ and $\mathrm{Cu}$ are essential elements, their excessive concentration in food and feed plants are of great concern because of their toxicity to humans and animals (Kabata-Pendias \& Mukherjee, 2007). When exceed their safe threshold values, $\mathrm{Cu}$ and $\mathrm{Zn}$ can cause non-carcinogenic hazardous such as neurologic involvement, headache and liver disease. As one of the highest toxic heavy metals, $\mathrm{Cd}$ is harmful to plant growth and human health. Dietary Cd intake through the food chain was associated with an increased risk of postmenopausal breast cancer, and its accumulation pose a serious health issue to humans, such as the "itai-itai" disease (Sun et al., 2013). Soil pollution has negative impacts on humans and the environment, especially for the ubiquitous and non-biodegradable heavy metals, the negative effects persist for several decades and even longer. Therefore, it is important to get information about heavy metal concentrations in food products and their dietary intake, and heavy metal pollution of soil and its impact on food security are receiving more attention (Akhtar, 2013; He et al., 2013; Römkens et al., 2009).

Rice production is the dominant agricultural activity in China, with rice forming the staple diet of more than $65 \%$ of the Chinese population (Zhang et al., 2005). China ranks as the second largest rice producer in the world. The mean consumption of rice grain in China is $206 \mathrm{~kg}$ per year per person (Zhang et al., 2005). Both the qualities of soil and rice produced are extremely closely related to local public health. Rice cultivated on soils polluted with $\mathrm{Cd}, \mathrm{Pb}, \mathrm{Cr}$, $\mathrm{Hg}, \mathrm{As}, \mathrm{Cu}, \mathrm{Ni}$ and $\mathrm{Zn}$ has been reported to accumulate the metals in root, leaf, stem and grain causing food-chain and ecotoxicological problems ( $\mathrm{Wu} \&$ Chen, 2013). For example, in the Zhangshi irrigation area of China, large amounts of $\mathrm{Cd}$ have accumulated in irrigated soils, and the cadmium content in rice grain, is also relatively high. Heavy metal accumulation in the soil-rice systems would poses potential environmental risks (Li et al., 2014).

Additionally, with the food structural adjustment of China in recent years, the consumption of vegetables for Chinese residents is also increasing greatly (Liu et al., 2005). Vegetables take up heavy metals by absorbing them from contaminated soils, as well as from deposits on parts of the vegetables exposed to the air from polluted environments. So as much as $50 \%$ of food intake may be assumed to be grown on contaminated soil in China, and long term consumption of food would pose a potentially high health risk caused by heavy metal exposure to consumers (He et al., 2013; Zhang et al., 2005). There are a series of standards on the tolerance limit of trace elements in foods (Table 2). According to this standard, the edibility of foods can be determined and the safety of foods can be guaranteed. Although some elements were lower than food standards, the heavy metal pollution cannot be ignored. The pollution in vegetables directly affects the health of humans via consumption. Fed with a diet containing $1 \mathrm{mg} / \mathrm{kg}$ of Cd for 12 days, the maximum of Cd in Nile tilapia was $0.129 \mathrm{mg} / \mathrm{kg}$, but declined to $86 \%$ following a no-Cd diet. Cd accumulated in the organism is not easy to excrete and affect the health of animals in the whole lifecycle. Although the levels 
of As in water and food were lower than the national food standard, the levels of As exposure of residuals were equal to or even over that of the severe cases of chronic arsenic poisoning reported in China, which occurred in the area with As concentrations in drinking water which were $0.18-0.85 \mathrm{mg} / \mathrm{kg}$.

\section{Remediation of Soil Contaminated with Heavy Metals}

The overall objective of any soil remediation approach is to create a final solution that is protective of human health and the environment. Effective methods for reducing soil heavy metal pollution involve severe control of pollution sources or strict implementation of environmental regulation in terms of waste discharge. Since the 1980s, much effort has been made to control pollution sources and to set up environmental quality standards in China. Some countermeasures for remediation of soil contaminated with heavy metals have been investigated including soil moisture management, amendment application, addition of organic manure, selection of crop varieties with a low uptake of heavy metals, and agro-ecological engineering techniques.

For heavy metal-contaminated soils, the physical and chemical form of the heavy metal contaminant in soil strongly influences the selection of the appropriate remediation treatment approach. USEPA (2010) has broadly classified remediation technologies for contaminated soils into 1) source control and 2) containment remedies. According to Table 3, there is another classification of remediation technologies for heavy metal-contaminated soils: isolation, immobilization, toxicity reduction, physical separation, and extraction.

Immobilization technology often uses organic and inorganic amendment to accelerate the attenuation of metal mobility and toxicity in soils (Wuana \& Okieimen, 2011). Because of the complexity of soil matrix and the limitations of current analytical techniques, the exact immobilization mechanisms have not been clarified, which could include precipitation, chemical adsorption and ion exchange, surface precipitation, formation of stable complexes with organic ligands, and redox reaction (Wang et al., 2009). Soil washing is essentially a volume reduction/waste minimization treatment process. It is done on the excavated soil or in situ. Acid and chelator soil washing are the two most prevalent removal methods. Phytoremediation, also called green remediation, botanoremediation, or vegetative remediation, can be defined as an in situ remediation strategy that uses vegetation and associated microbiota, soil amendments, and

Table 2. Tolerance limit of heavy metals in foods in China $[\mathrm{mg} / \mathrm{kg}]$.

\begin{tabular}{ccccccc}
\hline Foods types & $\mathrm{Cu}$ & $\mathrm{Zn}$ & $\mathrm{Pb}$ & $\mathrm{Cr}$ & As & $\mathrm{Cd}$ \\
\hline Crops & 10 & 50 & 0.4 & 1.0 & 0.7 & 0.05 \\
Vegetable & 10 & 20 & 0.2 & 0.5 & 0.5 & 0.05 \\
Fruit & 10 & 5 & 0.2 & 0.5 & 0.5 & 0.03 \\
\hline
\end{tabular}


Table 3. Technologies for remediation of heavy metal-contaminated soils.

\begin{tabular}{cc}
\hline Category & Remediation technologies \\
\hline Isolation & Capping \\
Immobilization & Subsurface barriers \\
& Solidification/stabilization \\
& Vitrification \\
Coxicity and/or mobility reduction & Chemical treatment \\
& Chemical treatment \\
& permeable treatment walls \\
Physical separation & biological treatment bioaccumulation, phytoremediation, \\
bioleaching, biochemical processes & \\
& Soil washing \\
& Pyrometallurgical extraction \\
& Electrokinetic treatment \\
\hline
\end{tabular}

agronomic techniques to remove, contain, or render environmental contaminants harmless (Helmisaari et al., 2007). Phytoremediation is energy efficient, aesthetically pleasing method of remediating sites with low-to-moderate levels of contamination, and it can be used in conjunction with other more traditional remedial methods as a finishing step to the remedial process (Figure 3). The advantages of phytoremediation are as follow: it is less disruptive, less risk of spreading the contamination, but more economically viable and more likely to be accepted by the public.

\section{Conclusion}

With the activity of humans, heavy metal pollution of soils becomes serious and even affects human health through the food chain during the last two decades in China. Although the geological background levels of heavy metals are low in China, both urban soils and agricultural soils are polluted by heavy metals. Nearly all the heavy metals concentrations of urban and agricultural soils are higher than their background values in China. Moreover, the concentrations of $\mathrm{Cd}$ and As in agricultural soils are higher than their background values. In agricultural area, intake of heavy metals via the soil-crop system has been considered as the predominant pathway of human exposure to environmental heavy metals; in urban area, heavy metals in urban soils and urban road dusts can be accumulated in human body via directly inhalation, ingestion and dermal contact absorption. The sources of heavy metals in urban soils and urban road dusts are mainly derived from traffic sources and industrial sources, but the sources of heavy metal in agricultural soils are mainly influenced by parent materials, mining, fertilization and pesticide application and so on. 


\section{Phytoremediation of Metal-Contaminated Soils}

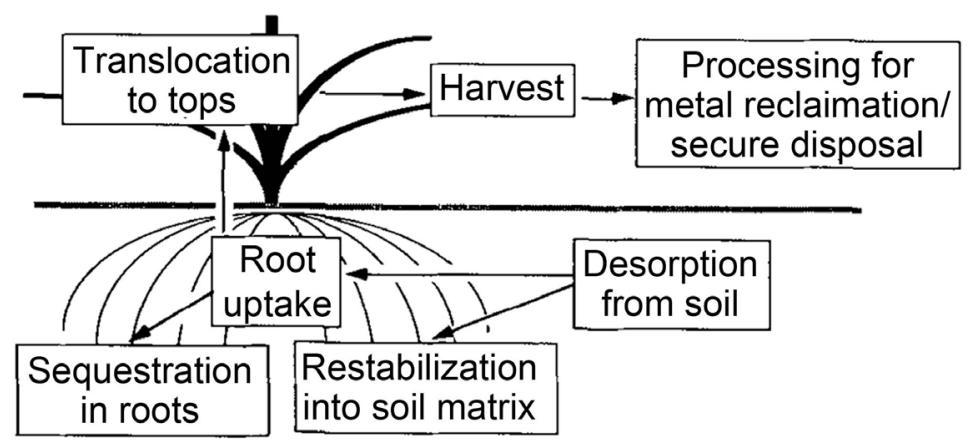

Figure 3. Scheme for the application of phytoremediation technology to metal-contaminated soils.

Heavy metals will accumulate in plants, and especially in foods to bring the toxicity and diseases to human beings, and this kind of pollution is covert, long-term and non-reversible. Thus, humans should be careful with heavy metal polluted water and food. To remediate and improve environmental quality is a long-term strategy for the polluted area to keep humans healthy and away from geological disease. Therefore, remediation of soil contaminated by heavy metals is necessary, which is a hot topic throughout the world. We have summarized some countermeasures for remediation of soil contaminated with heavy metals. Immobilization, soil washing and phytoremediation are frequently listed among the best available technologies for cleaning up heavy metal contaminated soils (Wuana \& Okieimen, 2011). As an optimum, a clean biosphere could be displayed in front of us in the near future.

\section{Acknowledgements}

This research was financially supported by the Natural Science Foundation of China (Nos. 41877006, 21876027 and 21577313).

\section{Conflicts of Interest}

The authors declare no conflicts of interest regarding the publication of this paper.

\section{References}

Adriano, D. C. (2003). Trace Elements in Terrestrial Environments: Biogeochemistry, Bioavailability and Risks of Metals (2nd Ed.). New York: Springer.

Akhtar, S. (2013). Food Safety Challenges-A Pakistan's Perspective.

Al-Saleh, I., Shinwari, N., El-Doush, I., Biuedo, G., Al-Amodi, M., \& Khogali, F. (2004). Comparison of Mercury Levels in Various Tissues of Albino and Pigmented Mice Treated with Two Different Brands of Mercury Skin-Lightening Creams. Biometals, 2, 167-175. https://doi.org/10.1023/B:BIOM.0000018377.17857.88 
Bosso, S. T., \& Enzweiler, J. (2008). Bioaccessible Lead in Soils, Slag, and Mine Wastes from an Abandoned Mining District in Brazil. Environmental Geochemistry and Health, 30, 219-229. https://doi.org/10.1007/s10653-007-9110-4

Cao, H. B., Chen, J. J., Zhang, J., Zhang, H., Qiao, L., \& Men, Y. (2010). Heavy Metals in Rice and Garden Vegetables and Their Potential Health Risks to Inhabitants in the Vicinity of an Industrial Zone in Jiangsu, China. Journal of Environmental Sciences, 22, 1792-1799. https://doi.org/10.1016/S1001-0742(09)60321-1

Chabukdhara, M., \& Nema, A. K. (2013). Heavy Metals Assessment in Urban Soils around Industrial Clusters in Ghaziabad, India: Probabilistic Health Risk Approach. Ecotoxicology and Environmental Safety, 87, 57-64. https://doi.org/10.1016/j.ecoenv.2012.08.032

Chen, J. (2007). Rapid Urbanization in China: A Real Challenge to Soil Protection and Food Security. Catena, 69, 1-15. https://doi.org/10.1016/j.catena.2006.04.019

De Miguel, E., Irribarren, I., Chacón, E., Ordoñez, A., \& Charlesworth, S. (2007). Risk-Based Evaluation of the Exposure of Children to Trace Elements in Playgrounds in Madrid (Spain). Chemosphere, 66, 505-513.

https://doi.org/10.1016/j.chemosphere.2006.05.065

Demek-Poprawa, M., \& Sawicka-Kapusta, K. (2004). Histopathological Changes in the Liver, Kidneys, and Testes of Bank Voles Environmentally Exposed to Heavy Metal Emissions from the Steelworks and Zinc Smelter in Poland. Environmental Research, 96, 8-72. https://doi.org/10.1016/j.envres.2004.02.003

Ferreira-Baptista, L., \& De Miguel, E. (2005). Geochemistry and Risk Assessment of Street Dust in Luanda, Angola: A Tropical Urban Environment. Atmospheric Environment, 39, 4501-4512. https://doi.org/10.1016/j.atmosenv.2005.03.026

Fu, S., \& Wei, C. Y. (2013). Multivariate and Spatial Analysis of Heavy Metal Sources and Variations in a Large Old Antimony Mine, China. Journal of Soils and Sediments, 13, 106-116. https://doi.org/10.1007/s11368-012-0587-9

He, B., Yun, Z., Shi, J., \& Jiang, G. (2013). Research Progress of Heavy Metal Pollution in China: Sources, Analytical Methods, Status, and Toxicity. Chinese Science Bulletin, 58, 134-140. https://doi.org/10.1007/s11434-012-5541-0

Helmisaari, H. S., Salemaa, M., Derome, J., Kiikkilo, O., Uhlig, C., \& Nieminen, T. M. (2007). Remediation of Heavy Metal Contaminated Forest Soil Using Recycled Organic Matter and Native Woody Plants. Journal of Environmental Quality, 36, 1145-1153. https://doi.org/10.2134/jeq2006.0319

Howard, W., \& Sammy, Z. (2012). The Urban Rise and Fall of Air Lead (Pb) and the Latent Surge and Retreat of Societal Violence. Environment International, 43, 48-55. https://doi.org/10.1016/j.envint.2012.03.005

Huang, S. S., Liao, Q. L., Hua, M., Wu, X. M., Bi, K. S., Yan, C. Y., Chen, B., \& Zhang, X. Y. (2007). Survey of Heavy Metal Pollution and Assessment of Agricultural Soil in Yangzhong District, Jiangsu Province, China. Chemosphere, 67, 2148-2155. https://doi.org/10.1016/j.chemosphere.2006.12.043

Itoh, H., Iwasaki, M., Sawada, N. et al. (2013). Dietary Cadmium Intake and Breast Cancer Risk in Japanese Women: A Case-Control Study. International Journal of Hygiene and Environmental Health, 217, 70-77. https://doi.org/10.1016/j.ijheh.2013.03.010

Jan, F. A., Ishaq, M., Ihsanullah, I., \& Asim, S. M. (2010). Multivariate Statistical Analysis of Heavy Metals Pollution in Industrial Area and Its Comparison with Relatively Less Polluted Area: A Case Study from the City of Peshawar and District Dir Lower. Journal of Hazardous Materials, 176, 609-616. https://doi.org/10.1016/j.jhazmat.2009.11.073 
Jarup, L. (2003). Hazards of Heavy Metal Contamination. British Medical Bulletin, 68, 82-167. https://doi.org/10.1093/bmb/ldg032

John, G. F., \& Andrew, B. (2011). A Lead Isotopic Study of the Human Bioaccessibility of Lead in Urban Soils from Glasgow, Scotland. Science of the Total Environment, 409, 4958-4965. https://doi.org/10.1016/j.scitotenv.2011.08.061

Kabata-Pendias, A., \& Mukherjee, A. B. (2007). Trace Elements from Soil to Human. New York: Springer-Verlag. https://doi.org/10.1007/978-3-540-32714-1

Kachenko, A. G., \& Singh, B. (2006). Heavy Metals Contamination in Vegetables Grown in Urban and Metal Smelter Contaminated Sites in Australia. Water, Air \& Soil Pollution, 169, 101-123. https://doi.org/10.1007/s11270-006-2027-1

Kapaj, S., Peterson, H., Liber, K., \& Bhattacharya, P. (2006). Human Health Effects from Chronic Arsenic Poisoning-A Review. Journal of Environmental Science and Health. Part A, Toxic/Hazardous Substances \& Environmental Engineering, 41, 2399-2428. https://doi.org/10.1080/10934520600873571

Kirpichtchikova, T. A., Manceau, A., Spadini, L., Panfili, F., Marcus, M. A., \& Jacquet, T. (2006). Speciation and Solubility of Heavy Metals in Contaminated Soil Using X-Ray Microfluorescence, EXAFS Spectroscopy, Chemical Extraction, and Thermodynamic Modeling. Geochimica et Cosmochimica Acta, 70, 2163-2190. https://doi.org/10.1016/j.gca.2006.02.006

Komárek, M., Chrastný, V., \& Mihaljevič, M. (2008). Lead Isotopes in Environmental Sciences: A Review. Environment International, 34, 562-577.

https://doi.org/10.1016/j.envint.2007.10.005

Krzysztof, L., Danuta, W., \& Irena, K. (2004). Metal Contamination of Farming Soils Affected by Industry. Environment International, 30, 159-165. https://doi.org/10.1016/S0160-4120(03)00157-0

Lai, H. Y., Hseu, Z. Y., Chen, T. C., Chen, B. C., Guo, H. Y., \& Chen, Z. S. (2010). Health Risk-Based Assessment and Management of Heavy Metals-Contaminated Soil Sites in Taiwan. International Journal of Environmental Research and Public Health, 7, 3595-3614. https://doi.org/10.3390/ijerph7103596

Li, J. W., Zhang, G. L., Ruan, L., Yang, J. L., \& Wang, H. L. (2016). Sr-Nd Elements and Isotopes as Tracers of Dust Input in a Tropical Soil Chronosequence. Geoderma, 262, 227-234. https://doi.org/10.1016/j.geoderma.2015.08.007

Li, W. L., Xu, B. B., Song, Q. J., Liu, X. M., Xu, J. M., \& Brookes, P. C. (2014). The Identification of Hotspots of Heavy Metal Pollution in Soil-Rice Systems at a Regional Scale in Eastern China. Science of the Total Environment, 472, 407-420. https://doi.org/10.1016/j.scitotenv.2013.11.046

Li, X. Y., Zuo, C. S., Tschirley, J. B., Webb, S. E., \& Morton, A. (1997a). Sustainable Agriculture and Rural Development in China, Part 1: The Agro-Ecosystem and China's Rural Economy. In Promotion of Sustainable Agriculture and Rural Development in China: Elements for a Policy Framework and a National Agenda 21 Action Programme. Beijing: FAO/UNDP/Ministry of Agriculture.

Li, X. Y., Zuo, C. S., Tschirley, J. B., Webb, S. E., \& Morton, A. (1997b). Sustainable Agriculture and Rural Development in China, Part 2: China's Transition to SARD. In Promotion of Sustainable Agriculture and Rural Development in China: Elements for a Policy Framework and a National Agenda 21 Action Programme. Beijing: FAO/UNDP/Ministry of Agriculture.

Li, X., Liu, L., Wang, Y., Luo, G., Chen, X., Yang, X., Hall, M. H. P., Guo, R., Wang, H., Cui, J., \& He, X. (2013). Heavy Metal Contamination of Urban Soil in an Old Industrial City (Shenyang) in Northeast China. Geoderma, 192, 50-58. 
https://doi.org/10.1016/j.geoderma.2012.08.011

Li, Y., Gou, X., Wang, G., Zhang, Q., Su, Q., \& Xiao, G. (2008). Heavy Metal Contamination and Source in Arid Agricultural Soils in Central Gansu Province, China. Journal of Environmental Sciences, 20, 607-612. https://doi.org/10.1016/S1001-0742(08)62101-4

Liao, Z. (1993). The Environmental Chemistry and Biological Effects of Microelement. Beijing: China Environmental Science Press. (In Chinese)

Lim, H., Lee, J., Chon, H., \& Sager, M. (2008). Heavy Metal Contamination and Health Risk Assessment in the Vicinity of the Abandoned Songcheon Au-Ag Mine in Korea. Journal of Geochemical Exploration, 96, 223-230. https://doi.org/10.1016/j.gexplo.2007.04.008

Lin, H. J., Sunge, T., Cheng, C. Y., \& Guo, H. R. (2013). Arsenic Levels in Drinking Water and Mortality of Liver Cancer in Taiwan. Journal of Hazardous Materials, 262, 1132-1138. https://doi.org/10.1016/j.jhazmat.2012.12.049

Ling, W., Shen, Q., Gao, Y., Gu, X., \& Yang, Z. (2007). Use of Bentonite to Control the Release of Copper from Contaminated Soils. Australian Journal of Soil Research, 45, 618-623. https://doi.org/10.1071/SR07079

Liu, W. X., Shen, L. F., Liu, J. W., Wang, Y. W., \& Li, S. R. (2007). Uptake of Toxic Heavy Metals by Rice (Oryza sativa L.) Cultivated in the Agricultural Soils near Zhengzhou City, People's Republic of China. Bulletin of Environmental Contamination and Toxicology, 79, 209-213. https://doi.org/10.1007/s00128-007-9164-0

Liu, W., Zhao, J., Ouyang, Z., Sorderlund, L., \& Liu, G. (2005). Impacts of Sewage Irrigation on Heavy Metal Distribution and Contamination in Beijing, China. Environment International, 31, 805-812. https://doi.org/10.1016/j.envint.2005.05.042

Liu, X., Wu, J., \& Xu, J. (2006). Characterizing the Risk Assessment of Heavy Metals and Sampling Uncertainty Analysis in Paddy Field by Geostatistics and GIS. Environmental Pollution, 141, 257-264. https://doi.org/10.1016/j.envpol.2005.08.048

Lu, Y., Gong, Z., Zhang, G., \& Burghardt, W. (2003). Concentrations and Chemical Speciations of $\mathrm{Cu}, \mathrm{Zn}, \mathrm{Pb}$ and $\mathrm{Cr}$ of Urban Soils in Nanjing, China. Geoderma, 115, 101-111. https://doi.org/10.1016/S0016-7061(03)00079-X

Lu, Y., Yin, W., Huang, L. B., Zhang, G. L., \& Zhao, Y. G. (2011). Assessment of Bioaccessibility and Exposure Risk of Arsenic and Lead in Urban Soils of Guangzhou City, China. Environmental Geochemistry and Health, 33, 93-102. https://doi.org/10.1007/s10653-010-9324-8

Madrid, L., Díaz-Barrientos, E., \& Madrid, F. (2002). Distribution of Heavy Metal Contents of Urban Soils in Parks of Seville. Chemosphere, 49, 1301-1308. https://doi.org/10.1016/S0045-6535(02)00530-1

Marjorie, C., Aeliona, H., Davisa, T., McDermottb, S., \& Lawsonc, A. B. (2008). Metal Concentrations in Rural Topsoil in South Carolina: Potential for Human Health Impact. Science of the Total Environment, 402, 149-156. https://doi.org/10.1016/j.scitotenv.2008.04.043

Maslin, P., \& Maier, R. M. (2000). Rhamnolipid-Enhanced Mineralization of Phenanthrene in Organic-Metal Co-Contaminated Soils. Bioremediation Journal, 4, 295-308. https://doi.org/10.1080/10889860091114266

McBride, M. B. (2007). Trace Metals and Sulfur in Soils and Forage of a Chronic Wasting Disease Locus. Environmental Chemistry, 4, 134-139. https://doi.org/10.1071/EN06066

McLaughlin, M. J., Hamon, R. E., McLaren, R. G., Speir, T. W., \& Rogers, S. L. (2000). Review: A Bioavailability-Based Rationale for Controlling Metal and Metalloid Contamination of Agricultural Land in Australia and New Zealand. Australian Journal of Soil 
Research, 38, 1037-1086. https://doi.org/10.1071/SR99128

Micó, C., Recatalá, L., Peris, M., \& Sánchez, J. (2006). Assessing Heavy Metal Sources in Agricultural Soils of an European Mediterranean Area by Multivariate Analysis. Chemosphere, 65, 863-872. https://doi.org/10.1016/j.chemosphere.2006.03.016

Miraglia, M., Marvin, H. J. P., Kleter, G. A., Battilani, P., Brera, C., Coni, E. et al. (2009). Climate Change and Food Safety: An Emerging Issue with Special Focus on Europe. Food and Chemical Toxicology, 47, 1009-1021. https://doi.org/10.1016/j.fct.2009.02.005

Montagne, D., Cornu, S., Bourennane, H., Baize, D., Ratié, C., \& King, D. (2007). Effect of Agricultural Practices on Trace-Element Distribution in Soil. Communications in Soil Science and Plant Analysis, 38, 473-491. https://doi.org/10.1080/00103620601174411

Nicholson, F. A., Smith, S. R., Alloway Carlton-Smithd, C., \& Chambers, B. J. (2003). An Inventory of Heavy Metals Inputs to Agricultural Soils in England and Wales. Science of the Total Environment, 311, 205-219. https://doi.org/10.1016/S0048-9697(03)00139-6

Oliver, M. A. (1997). Soil and Human Health: A Review. European Journal of Soil Science, 48, 573-592. https://doi.org/10.1046/j.1365-2389.1997.00124.x

Park, R. M., Bena, J. F., Stayner, L. T., Smith, R. J., Gibb, H. J., \& Lees, P. S. (2004). Hexavalent Chromium and Lung Cancer in the Chromate Industry: A Quantitative Risk Assessment. Risk Analysis, 24, 1099-1108. https://doi.org/10.1111/j.0272-4332.2004.00512.x

Poggio, L., Vı̌šcaj, B., Hepperle, E., Schulin, R., \& Marsan, F. A. (2008). Introducing a Method of Human Health Risk Evaluation for Planning and Soil Quality Management of Heavy Metal-Polluted Soils-An Example from Grugliasco (Italy). Landscape and Urban Planning, 88, 64-72. https://doi.org/10.1016/j.landurbplan.2008.08.002

Pruvot, C., Douay, F., Herve, F., \& Waterlot, C. (2006). Heavy Metals in Soil, Crops and Grass as a Source of Human Exposure in the Former Mining Areas. Journal of Soils and Sediments, 6, 20-215. https://doi.org/10.1065/jss2006.10.186

Rogan, N., Serafimovski, T., Dolenec, M., Tasev, G., \& Dolenec, T. (2009). Heavy Metal Contamination of Paddy Soils and Rice (Oryza sativa L.) from Kočani Field (Macedonia). Environmental Geochemistry and Health, 31, 439-451.

https://doi.org/10.1007/s10653-008-9197-2

Römkens, P., Guo, H. Y., Chu, C. L., Liu, T. S., Chiang, C. F., \& Koopmans, G. F. (2009). Prediction of Cadmium Uptake by Brown Rice and Derivation of Soil-Plant Transfer Models to Improve Soil Protection Guidelines. Environmental Pollution, 157, 2435-2444. https://doi.org/10.1016/j.envpol.2009.03.009

Sriprachote, A., Kanyawongha, P., Ochiai, K., \& Matoh, T. (2012). Current Situation of Cadmium-Polluted Paddy Soil, Rice and Soybean in the Mae Sot District, Tak Province, Thailand. Soil Science and Plant Nutrition, 58, 349-359. https://doi.org/10.1080/00380768.2012.686435

Sun, Y., Sun, G., Xu, Y., Wang, L., Liang, X., \& Lin, D. (2013). Assessment of Sepiolite for Immobilization of Cadmium-Contaminated Soils. Geoderma, 193-194, 149-155. https://doi.org/10.1016/j.geoderma.2012.07.012

Wang, L. Q., Luo, L., Ma, Y. B., Wei, D. P., \& Hua, L. (2009). In Situ Immobilization Remediation of Heavy Metals-Contaminated Soils: A Review. Chinese Journal of Applied Ecology, 20, 1214-1222.

Wang, X. C., Yan, W. D., An, Z., Lu, Q., Shi, W. M., Cao, Z. H., \& Wong, M. H. (2003). Status of Trace Elements in Paddy Soil and Sediment in Taihu Lake Region. Chemos- 
phere, 50, 707-710. https://doi.org/10.1016/S0045-6535(02)00209-6

Wei, B., \& Yang, L. (2010). A Review of Heavy Metal Contaminations in Urban Soils, Urban Road Dusts and Agricultural Soils from China. Microchemical Journal, 94, 99-107. https://doi.org/10.1016/j.microc.2009.09.014

Wu, Y., \& Chen, Y. (2013). Food Safety in China. Journal of Epidemiology and Community Health, 67, 478-489. https://doi.org/10.1201/b17261

Wuana, R. A., \& Okieimen, F. E. (2011). Heavy Metals in Contaminated Soils: A Review of Sources, Chemistry, Risks and Best Available Strategies for Remediation. ISRN Ecology, 2011, Article ID: 402647. https://doi.org/10.5402/2011/402647

Yan, X., Gao, D., Zhang, F., Zeng, C., Xiang, W., \& Zhang, M. (2013). Relationships between Heavy Metal Concentrations in Roadside Topsoil and Distance to Road Edge Based on Field Observations in the Qinghai-Tibet Plateau, China. International Journal of Environmental Research and Public Health, 10, 762-775.

https://doi.org/10.3390/ijerph10030762

Yang, P., Mao, R., Shao, H., \& Gao Y. (2009). The Spatial Variability of Heavy Metal Distribution in the Suburban Farmland of Taihang Piedmont Plain, China. Comptes Rendus Biologies, 332, 558-566. https://doi.org/10.1016/j.crvi.2009.01.004

Zhang, M., \& Gong, Z. (1996). Content and Distribution of Several Heavy Metals in Vegetable Fields in China. Acta Soil Sinica, 33, 85-93. (In Chinese)

Zhang, X., Wang, D., Fang, F., Zhen, Y., \& Liao, X. (2005). Food Safety and Rice Production in China. Research of Agricultural Modernization, 26, 85-88. (In Chinese)

Zhao, Y. F., Shi, X. Z., Huang, B., Yu, D. S., Wang, H. J., Sun, W. X., Öboern, I., \& Blombäck, K. (2007). Spatial Distribution of Heavy Metals in Agricultural Soils of an Industry-Based Peri-Urban Area in Wuxi, China. Pedosphere, 17, 44-51.

https://doi.org/10.1016/S1002-0160(07)60006-X

Zhao, Z., Rate, A. W., Tang, S., \& Bi, H. (2007). Characteristics of Heavy Metals Distribution in Agricultural Soils of Hainan Island and Its Environment Significances. Journal of Agro-Environment Science, 27, 182-187.

Zheng, N., Wang, Q. C., \& Zheng, D. M. (2007). Health Risk of Hg, Pb, Cd, Zn, and Cu to the Inhabitants around Huludao Zinc Plant in China via Consumption of Vegetables. Science of the Total Environment, 383, 9-81.

https://doi.org/10.1016/j.scitotenv.2007.05.002 